\title{
THE BRITISH SOCIAL DEMOCRATIC FEDERATION 1880-1885
}

\author{
FROM O'BRIENISM TO MARXISM*
}

SUMMARY:A number of Bronterre O'Brien's disciples were the leading lights of the London clubs that provided the silent majority to the Social Democratic Federation (S.D.F.). Even after the O'Brienites came to accept the need for collective ownership of the means of production, their political strategy remained that of $O^{\prime} B$ rien. An understanding of the role played by the O'Brienites helps to explain various problems in the history of the S.D.F. such as why most members remained with Hyndman rather than follow Morris into the Socialist League and why the S.D.F. adopted an ambiguous attitude to trade unions and to palliatives.

\section{Introduction}

The emergence of socialism from radicalism remains a fairly obscure process. We know that Hyndman grafted a form of orthodox Marxism onto Tory radicalism, we know that Morris became disillusioned with Gladstonian radicalism, and we know that the leading Fabians moved from various types of liberal radicalism to Fabian socialism. ${ }^{1}$ But what of the relatively silent membership of the Social Democratic Federation (S.D.F.), the first socialist society of the $1880 \mathrm{~s} ?^{2}$ How did they come to demand collective ownership of the means of production? Recently labour historians have shifted their emphasis from the rise of an industrial proletariat to the persistence of skilled artisans. ${ }^{3}$ I believe that, as this shift of emphasis might

* I presented an earlier version of this paper to the 1988 seminar on British History in the Nineteenth and Twentieth Centuries at Oxford University; I thank those present for their helpful comments. In particular, I thank Jose Harris, James Meadowcroft, and Philip Waller for reading and commenting on earlier drafts of this paper.

'On Hyndman see C. Tsuzuki, H.M. Hyndman and British Socialism (Oxford, 1961) and M. Bevir, "H.M. Hyndman: A Rereading and a Reassessment", History of Political Thought, XII (1991), pp. 125-145. On Morris see E.P. Thompson, William Morris: From Romantic to Revolutionary (London, 1977). On the Fabians see W. Wolfe, From Radicalism to Socialism (New Haven, 1975).

${ }^{2}$ For previous accounts of the S.D.F. see H. Lee and E. Archbold, Social-Democracy in Britain (London, 1935); Tsuzuki, Hyndman, and M. Wilkins, "The Non-Socialist Origins of England's First Important Socialist Organisation", International Review of Social History, IV (1959), pp. 199-207.

${ }^{3}$ See, for instance, R. Samuel, "The Workshop of the World: Steam Power and Hand Technology in Mid-Victorian Britain", History Workshop, 3 (1977), pp. 6-72, and G. Stedman Jones, "Rethinking Chartism", in Languages of Class: Studies in English 
suggest, many of the early members of the S.D.F. were O'Brienites whose socialism remained tinged with O'Brienism. ${ }^{4} \mathrm{Here}$, then, is another chapter in the story of the transformation of radicalism into socialism.

\section{James Bronterre O'Brien (1804-1864)}

James Bronterre O'Brien was an Irishman who settled in England and became the "schoolmaster of the Chartists". ${ }^{5}$ O'Brien's political theory centred on the undemocratic nature of the British political system. He argued that social evils had political causes. The ruling classes had a monopoly of the legislative process and this enabled them to introduce oppressive laws under which the few robbed the many. O'Brien told the workingman that "it is because you are unrepresented that you have no property", and that "wages-slavery is wholly and solely the work of tyrannical laws which one set of men impose upon another by fraud and force". 6

Although social evils had political causes, they were nonetheless real evils, the worst of which were the private ownership of the land and the current systems of currency and exchange: "unquestionably land-usurpers and money-changers [ . . .] must in foco conscienta be distinguished from all other sinners" since "we know of no great social evil in civilized life that is not clearly traceable, directly or indirectly, to these two classes". ${ }^{7} \mathrm{O}^{\prime} \mathrm{Brien}$ believed God had given the land to all people, but a small section of the population had used unjust laws to take the land for themselves. Further, because the amount of land is fixed, the private appropriation of the land had denied the propertyless masses the chance to produce their own subsistence and so forced them to work for the land owners. Thus, O'Brien concluded, the moment you allow the few to monopolise the land, "your community is divided into tyrants and slaves - into knaves who will work for nobody, and into drudges who will have to work for anybody or everybody but themselves". ${ }^{8}$ The private ownership of land divides society into opposing classes and underlies all other social wrongs.

O'Brien also criticised the moneylords who cheat society under the current systems of currency and exchange. Because the currency rests on

Working Class History 1832-1982 (Cambridge, 1983), pp. 90-178.

${ }^{4}$ Previous accounts present the S.D.F.'s Marxism as dogmatic and revolutionary. See H. Collins, "The Marxism of the Social Democratic Federation", in A. Briggs and J. Saville (eds), Essays in Labour History, (London, 1971); S. Pierson, Marxism and the Origins of British Socialism (Ithaca, 1973), and Wolfe, Radicalism.

5 A. Plummer, Bronterre: A Political Biography of Bronterre O'Brien 1804-1864 (London, 1971).

${ }^{6}$ National Reformer, 3 October 1846; J. O'Brien, The Rise, Progress, and Phases of Human Slavery (London, 1885), p. 94.

$?$ O'Brien, Rise, p. 128.

${ }^{8}$ Ibid., p. 127. 
commodities, gold and silver, the moneylords who monopolise these precious metals also monopolise the currency, and so "leave us without any instruments of exchange at all, but what may be convertible, upon their own fraudulent terms, into those two favoured metals". ${ }^{9}$ Further, the moneylords use their parliamentary power to manipulate both the money supply and the national debt for their personal advantage. Peel, for instance, both promoted laissez-faire which increased foreign competition and so lowered the value of commodities, and tightened the money supply which raised the value of money compared to commodities and so lowered the value of commodities. Now, the falling value of commodities swelled fixed money obligations, such as debts and taxes, and this "must reduce the aggregate of profits and wages, for the more the producers (employers and employed) have to give out of the common stock to pay taxes and the interest of public and private debts, the less there must be left for themselves". ${ }^{10}$ The moneylords, however, benefitted from Peel's policies since they possessed monetary assets, such as fixed interest stocks, the value of which increased relative to commodities. Finance, therefore, was the common enemy of labour and capital.

Indeed, O'Brien criticised capitalists only because they sometimes acted as moneylords or middlemen. Like moneylords, capitalists issued debt so as to gain at the expense of the workingman:

The mercantile middle-classes are everywhere organising chartered companies to give themselves perpetual vested interests in the labour of the workingclasses, and mortgage the latter to posterity through public loans and State indebtedness. ${ }^{11}$

Similarly, O'Brien complained about "middlemen who [. . . get their living by buying your [the workingman's] labour at one price and selling it [. . .] at another". ${ }^{12}$ Although O'Brien attacked capitalists for behaving like moneylords or middlemen, he believed that capitalists could behave like this only because the people had no access to the land: "the monopoly of the land in private hands is a palpable invasion of the rights of the excluded parties, rendering them more or less the slaves of landlords and capitalists". ${ }^{13}$

The fundamental oppositions in O'Brien's writings were those of popular radicalism between rulers and people and between workers and idlers. The few who possessed a monopoly of political power used the law to defraud the many - the rulers opposed the people. Viewed from a social perspec-

9 Ibid., p. 135.

${ }^{10}$ Ibid., p. 122.

"Ibid., p. 144.

${ }^{12}$ Poor Man's Guardian, 15 December 1832.

${ }^{13}$ O'Brien, Rise, p. 101. 
tive, the opposition of rulers to people was equivalent to the opposition between workers and idlers, for the rulers used their political power to obtain "incomes" that were "purely and wholly the creation of law, and not of their own labour". ${ }^{14}$ Thus, the unequal distribution of political power created "an unnatural division of society into classes, viz., those who labour and produce as well as consume, and those who consume only". ${ }^{15}$

O'Brien's proposals for reform grew out of his analysis of the problems of contemporary society. Because the unrepresentative political system underlay current social evils, "we must first have political equality". ${ }^{16}$ Thus, O'Brien called above all else for the implementation of the Charter, the six points of which were universal suffrage, annual parliaments, no property qualifications for M.P.'s, payment of M.P.'s, voting by a secret ballot, and equal electoral districts. ${ }^{17} \mathrm{He}$ believed that the political reforms of the Charter, especially manhood suffrage, would create a representative political system that would give the people the legislative power needed to eradicate poverty and slavery: "manhood suffrage must be the cry and watchword [ . . .] to get honest laws passed upon Land, Credit, Currency, and Exchange". ${ }^{18}$ Initially O'Brien was a physical force Chartist but after his imprisonment in 1840 he became a moral force Chartist. At times O'Brien seemed to put social reform above political reform, as when he said that "a reform of parliament can effect little good except in so far as it may conduce to a reform in the construction of society". ${ }^{19}$ But even if his goal was social reform, the means remained political reform. As he said, "the end $I$ have in view is social equality for each and all, to obtain this we must first have political equality". ${ }^{20}$

O'Brien thought that a Land Nationalisation Act was the most important piece of legislation required of a reformed parliament. Nationalising the land would free the people from the tyranny of the landlords and the capitalists. It would enable the people to work the land for themselves and so produce their own livelihood - the many would no longer have to work for the few. Land nationalisation was the vital social reform:

\footnotetext{
${ }^{14}$ Ibid., p. 113.

15 "Bronterre's Second Letter to the People of England", Political Letters and Pamphlets, 12 February 1831.

${ }^{16}$ National Reformer, 7 January 1837.

${ }^{17}$ On chartism see, particularly, Stedman Jones, "Chartism"; but also, A. Briggs (ed.), Chartist Studies (London, 1959); J. Epstein and D. Thompson (eds), The Chartist Experience: Studies in Working Class Radicalism and Culture 1830-1860 (London, 1982); C. Godfrey, Chartist Lives: The Anatomy of a Working-Class Movement (New York, 1987), and D. Thompson, The Chartists (London, 1984).

${ }^{18}$ National Reform League Tract No. 5, November 1855.

${ }^{19}$ Proceedings of 2nd Co-operative Congress. Cited by Plummer, Bronterre, p. 38.

${ }^{20}$ National Reformer, 7 January 1837.
} 
No reform that will not give the people the means of acquiring property by honest industry - which will not enable them to be independent of wages-slavery - which will not enable them to live in houses of their own, and allow them free access to the soil of their country, is worth their serious attention. ${ }^{21}$

Similarly, O'Brien's "currency quackery" was the social reform that he thought would end the tyranny of the moneylords. The moneylords could rob the people only because gold and silver were both commodities and the basis of the currency. Consequently $\mathrm{O}^{\prime} B$ rien proposed a paper currency "based on real consumable wealth", that is on labour or on corn (generally he preferred labour). ${ }^{22} \mathrm{~A}$ currency founded on labour would not fluctuate according to the availability of precious metals and so would ensure a true equilibrium between production and consumption. A person who produced goods worth $X$ would be given currency worth $X$ with which to buy consumables. There would be no way to make money yield more money and so no room for the moneylord. Finally, O'Brien called for a system of direct exchange and state stores in order to eliminate parasitic middlemen. Nowhere did he demand collective ownership of the means of production.

\section{London Clubland 1864-1881}

When O'Brien died he left behind a group of followers many of whom later joined the S.D.F. Charles Murray supervised the arrangements for O'Brien's funeral, and in 1884 the S.D.F.'s newspaper, Justice, advertised his lecture on "Personal Recollections of Bronterre O'Brien". ${ }^{23}$ His brother James Murray was a chief mourner at O'Brien's funeral, and in 1883 he sat on the D.F.'s executive committee. ${ }^{24}$ George Harris wrote a letter to Victor Hugo asking him to give a speech at O'Brien's funeral, and he later spoke to the Marylebone branch of the S.D.F. on "Socialism vs. Liberalism".25 Hyndman described a walk back from an S.D.F. meeting with two more of O'Brien's followers, William Morgan and Richard Butler. ${ }^{26}$ And finally

"O'Brien, Rise, p. 127.

22 Ibid., p. 102.

${ }^{23}$ On Charles Murray's organisation of O'Brien's funeral see, Plummer, Bronterre, $\mathrm{p}$. 269; and, for the announcement of Charles Murray's lecture see Justice, 15 November 1884. For confirmation that Charles Murray was an O'Brienite when he joined the S.D.F. see H. Hyndman, The Record of an Adventurous Life (London, 1912), p. 246; and, Lee and Archbold, Social-Democracy, p. 245. For Charles Murray's views see C. Murray, A Letter to Mr. George Jacob Holyoake (London, 1854).

${ }^{24}$ For a report of the funeral see Reynolds's, 8 January 1865 . As a member of the D.F.'s executive James Murray signed, The Democratic Federation, Socialism Made Plain: Being the Social and Political Manifesto of The Democratic Federation (London, 1883). ${ }^{25}$ On the letter see Plummer, Bronterre, p. 268; on the lecture see Christian Socialist, September 1883. 
there was William Townshend who Max Beer found selling his books and as ready as ever to talk politics and praise O'Brien. ${ }^{27}$

The O'Brienites were not idle in the period separating Chartism from the socialism of the $1880 \mathrm{~s}$, and they did not restrict their activities to the National Reform League (N.R.L.) which O'Brien had founded in 1849. Harris and Charles Murray were among the British representatives at the meeting that inspired the formation of the International Working Men's Association, and these two, Townshend, and George Milner all served on the General Council of the International. ${ }^{28}$ The Holborn branch of the N.R.L. organised the 1869 Bell Inn Conference that founded the Land and Labour League.$^{29}$ Finally, the O'Brienites participated in the republican movement of the early 1870 s and were amongst the few republicans who defended the Paris Commune of 1871 - James Murray helped to organise a pro-Commune rally in Hyde Park. ${ }^{30}$

Despite Marx's undoubted intellectual power, he did not convince those O'Brienites who participated in the International that collective ownership of the means of production was necessary. On the contrary, Charles Murray spoke of "just laws on land, credit, currency, and exchange" as "identical with those on which the International was based" ${ }^{31}$ And in the twentieth century Townshend still felt that $O^{\prime} B$ rien could have defended their corner - "I wish Bronterre O'Brien had lived a few years longer, he would have been the man to argue currency matters out with Marx". ${ }^{32}$ Indeed, Marx himself acknowledged that despite their usefulness the O'Brienites disagreed with him. He wrote that, "these O'Brienites, in spite of their follies, constitute an often necessary counterweight to trade unionists" since "they are more revolutionary, firmer on the land question, and not susceptible to bourgeois bribery". ${ }^{33}$

The early 1870 s saw the collapse of many of the radical organisations that the O'Brienites had supported: the International and the Land and Labour League faded away, the republican movement disintegrated after the Commune, and, worst of all from the O'Brienites point of view, the Reform ${ }^{26}$ Hyndman, Record, p. 254.

${ }^{27}$ M. Beer, Fifty Years of International Socialism (London, 1935), pp. 13-14.

${ }^{28} \mathrm{H}$. Collins and C. Abramsky, Karl Marx and the British Labour Movement (London, 1965).

${ }^{29}$ R. Harrison, Before the Socialists (London, 1965), pp. 210-250.

${ }^{30}$ On the republican movement see, N. Gossman, "Republicanism in Nineteenth Century England", International Review of Social History, VII (1962), pp. 47-60; Harrison, Before the Socialists; and E. Royle, Radicals, Republicans, and Secularists (Manchester, 1980). On the defenders of the Commune, though the O'Brienites receive inadequate attention, see R. Harrison (ed.), The English Defence of the Commune (London, 1971). For James Murray's role in the Hyde Park rally see Justice, 9 March 1889.

31 International Herald, 1 June 1877.

32 Beer, Fifty Years, p. 14.

${ }_{33}$ K. Marx and F. Engels, Letters to the Americans 1848-1895 (New York, 1953), p. 89. 
League disbanded after the passing of the 1867 Reform Bill even though the Bill had not introduced manhood suffrage. In 1874 Morgan led the O'Brienites in founding the Manhood Suffrage League (M.S.L.) to fill the gap left by the demise of so many radical organisations. ${ }^{34}$ The formation of the M.S.L. reflected a broad shift in the pattern of workingmen's radical politics. As the big umbrella organisations weakened, so radical workingmen retreated into local clubs. The Stratford Dialectical and Radical Club, for instance, broke from the local branch of the National Secular Society because local members wanted to engage with political issues and not limit themselves to anti-theological work. ${ }^{35}$

Fun, education, and politics all went together in the London clubs. Club members might meet in a pub to hear a talk on the poetry of Shelley and end up discussing his politics - Tom Mann, later an active member of the S.D.F., tells us how his Shakespeare Mutual Improvement Society rented a room at the Devonshire Club in Chiswick. ${ }^{36}$ The O'Brienites concentrated on the M.S.L., but their influence extended throughout London clubland. Members of the M.S.L. often joined other clubs: Pottle belonged to the M.S.L., the West Central Democratic Club, and the Clerkenwell Patriotic Club. ${ }^{37}$ And members of the M.S.L. often gave talks at other clubs as did Charles Murray at the Rose Street Club. ${ }^{38}$ Indeed, whilst some club members already held radical views others learnt their radicalism from the O'Brienites before going on to join the Marxist groups of the 1880s. Clubland figures who later joined the S.D.F. include the poet John Leno of the M.S.L., Edwin Dunn who was the Secretary of the Marylebone Democratic Association and who denounced political economy at the Claremont Eclectic Debating Society, Tom Lemon who instigated the break between the Stratford Dialectical and Radical Club and the National Secular Society, Lord who was President of the English Section of the Rose Street Club, John Williams also of the Rose Street Club, and James Macdonald of the Marylebone Democratic Association who said he was converted to social-

${ }^{34}$ On the London clubs see, S. Shipley,, "Club Life and Socialism in Mid-Victorian England", History Workshop Pamphlet No. 5 (1971) - this pioneering work rescued the clubs from historical obscurity, but it suffers from Shipley's overbearing insistence on presenting his subjects as model socialists. For contemporary accounts from contrasting perspectives see H. Mayhew, Report Concerning the Trade and Hours of Closing Usual Among the Unlicensed Victualling Establishments at Certain So-called "Working Men's Clubs" (London, n.d.), and T. Oakey, A Basketful of Memories (London, 1930). On the continuation of club life in a socialist milieu see S. Macintyre, A Proletarian Science (London, 1986).

${ }^{35}$ Shipley, Club Life, pp. 40-41

${ }^{36}$ T. Mann, Memoirs (London, 1923), pp. 11-20.

${ }^{37}$ See, International Herald, 12 October 1872, and A. Rothstein, A House on Clerkenwell Green (London, 1983). The Clerkenwell Patriotic Club was founded by Tom Mottershed who had sat on the General Council of the International.

${ }^{38}$ The Republican, April 1880. 
ism by the O'Brienites. ${ }^{39}$ Given the prominent role of the O'Brienites in the London clubs, we should not be surprised that Frank Kitz, who himself graduated from the clubs to various Marxist and anarchist groups, later said that the members of the M.S.L. "were the chief actors in bringing about the revival of socialism". 40

It was, however, Hyndman who provided the major impetous behind the creation of the S.D.F. ${ }^{41}$ Inspired by reading a copy of Capital, he called on Disraeli to discuss how best to avert violent revolution, and when Disraeli told him that vested interests paralysed the Conservatives, he decided to try to create a new political party. In order to find support for his venture Hyndman approached the Rose Street Club and, on 30 October 1881, lectured to the M.S.L. on "The Tyranny of Capital in America and England" ${ }^{42}$ Indeed, Hyndman and his Tory friends called the inaugural conference of the Democratic Federation (D.F.) only after they "had gathered around us enough of the Radical Clubs and Irish communities" ${ }^{43}$ It was Edwin Dunn who sent out the invitations to the inaugural meeting of the D.F.

Many clubs withdrew from the D.F. late in 1881 after the D.F. issued a manifesto that attacked "the hollowness and hypocrisy of capitalist Radicalism". ${ }^{44}$ Shortly afterwards, however, Hyndman wrote a letter that clearly shows that the O'Brienites remained within the S.D.F. He said that "the Liberal wirepullers, specially paid for that purpose, are at work taking the Clubs from us [ . . . ] for my part I have thrown in my lot with the Federation [. . .] Charles Murray and all the old ' 48 men are heartily with us". 45 Hyndman, Morris, Champion, and Aveling, these we know about, but little has been said about the silent S.D.F. members from the London clubs.

${ }^{39}$ See J. Leno, Drury Lane Lyrics (London, 1868); on Dunn, Labour Standard, 11 February 1882; on Lemon, Shipley, Club Life, pp. 41-43; on Williams, Justice, 21 July 1894, and on Macdonald, Justice, 11 July 1896.

${ }^{40}$ Kitz wrote an autobiography in Freedom January-July 1912. The reference is to Freedom, February 1912.

${ }^{41}$ On Hyndman see Bevir, "Hyndman"; Tsuzuki, Hyndman; Hyndman, Record; H. Hyndman, Further Reminiscences (London, 1912), and R. Hyndman, Last Years of H.M. Hyndman (London, 1923).

${ }^{42}$ For Hyndman at Rose Street see Justice, 21 July 1894; for Hyndman's lecture to the M.S.L. see National Reformer, 30 October 1881, and on Hyndman and the clubs in general see Hyndman, Record, pp. 246-248.

${ }_{43}$ Hyndman, Record, p. 247.

44 Justice, 4 August 1884.

${ }^{45}$ Mill-Taylor Correspondence, cited by Tsuzuki, Hyndman, p. 47. Tsuzuki says "all" the clubs left the D.F., but this was not so. His source is Justice, 9 August 1884 which is an unreliable self-assessment; thus, Tsuzuki himself rightly disparages the claim, found in the same article, that the D.F. was a committed socialist organisation from the moment it was founded. 


\section{O'Brienism in the Democratic Federation 1881-1883}

O'Brienism was the language of the members of the S.D.F. Political representation was the major concern of those present at the preliminary meetings to found the D.F. ${ }^{46}$ The first meeting passed a motion that declared that "the present system of electing members of parliament has resulted in 'the exclusion of any representative of the majority of the people",. ${ }^{47}$ Dunn acted as a spokesman for the workingmen who attended the preliminary meetings and his letter to the Radical shows that he thought that political imbalances were the cause of current social ills: ${ }^{48}$

We live in an age when every class is united, and is duly represented in Parliament, save that of the majority of the nation. The landholders are united and bound by one common interest; they govern of course the House of Lords, and have many representatives in the Commons [. . .]. So with the other classes, all are organised, and use their organisation to subdue and keep in subjugation the labouring masses of the people. Such being the case it cannot be wondered at that our laws are framed and our taxes arranged so that the people bear the burden. ${ }^{49}$

Like O'Brien, Dunn juxtaposed the ruling classes with the people and argued that the cause of the people's plight was the fact that they were not represented in Parliament. The preliminary meetings also adopted reforms that assumed an analysis of society similar to that of O'Brien with the first meeting accepting a provisional programme of purely political reforms. Indeed, political concerns dominated to such an extent that there was no mention of any social measure until the third meeting when Finlayson proposed that they accept nationalisation of the land. ${ }^{50}$ The delegates did not ignore social questions. On the contrary, they wanted a movement "having for its object the promotion and settlement of the various social and political questions of the day". ${ }^{51}$ But they thought the way to solve social problems was by political reforms.

The same beliefs pervaded the inaugural conference of the D.F. ${ }^{52} \mathrm{Hynd}-$

${ }^{46}$ I have found the following reports of the preliminary meetings in 1881: the 1st meeting, Radical, 5 March, and Echo, 3 March: the second meeting, Daily News, 7 March, and Radical, 12 March: the third meeting, Observer, 20 March, and Daily News, 21 March.

${ }^{47}$ Radical, 5 March 1881.

${ }^{48}$ On Dunn's role see, Daily News, 7 March 1881, and Radical, 12 March 1881.

${ }^{49}$ Radical, 12 March 1881.

so Daily News, 21 March 1881.

${ }^{51}$ Daily News, 7 March 1881.

${ }^{52}$ I have found the following accounts of the inaugural conference: Daily News, 9 June 1881; Echo, 9 June 1881; Pall Mall Gazette, 9 June 1881; St James's Gazette, 9 June 1881; The Times, 9 June 1881, and Reynolds's, 12 June 1881. 
man's opening address firmly established the political purport of the meeting. He said that "the conference had been called together because there was so little general harmony between Democratic and Radical organisations in this country, the consequence of which was that motion after motion was passed through the House of Commons contrary to the feelings of both parties". ${ }^{53}$ The meeting, he continued, would begin by considering the question of the franchise since "the voting in this country was confined to too few". ${ }^{54}$ After Hyndman's speech, the delegates adopted a series of resolutions all of which called for political reforms apart from one which demanded nationalisation of the land. Finally, Justin M'Carthy explained that the Irish problem stemmed from an unjust distribution of political power that sustained social exploitation: "the Liberal Party had in his opinion gone to shipwreck, as those formerly belonging to it had lately been going in for all the old, discreditable, abominable weapons of coercion and oppression to enable alien landlords to squeeze rack rents out of an oppressed peasantry". ${ }^{55}$ Once again the solution was political: "what Irishmen most wanted was a domestic Parliament". ${ }^{56}$

The declared object of the D.F. was to unite "Democrats and workers throughout Great Britain and Ireland" and so advance the reforms laid out in its programme.$^{57}$ The D.F.'s programme opened with those demands of the Charter that had not yet been met - adult suffrage, triennial parliaments, equal electoral districts, and payment of members - after which there followed several other political measures - corrupt practices to be made illegal, abolition of the House of Lords, legislative independence for Ireland, and national and federal parliaments throughout the Commonwealth - and finally there came O'Brien's main social reform, the nationalisation of the land.

Hyndman hoped the D.F. would capture the support of all radicals, but the O'Brienites pushed him faster than he wanted to go and propelled the D.F. to the extreme edge of popular radicalism. They talked of the struggle between labour and capital and of the need for a social revolution. Their analysis, however, remained that of O'Brien. They distinguished the people or working classes from the rulers or idle classes. They saw political power as the crucial prop of economic oppression. And they gave the land monopoly a special place amongst social evils - the struggle might be labour against capital but all social evils could still be ended by giving the workers access to the land and so making it unnecessary for the workers to be wage slaves.

53 Daily News, 9 June 1881.

s4 lbid.

${ }_{55}$ Ibid.

${ }_{56}$ Ibid.

57 Radical, 16 July 1881. 
The beliefs of the O'Brienites at this time are clear from the proceedings of the annual conference of the D.F. in 1882. When Mr. Jones proposed "that the establishment of a British Republic be added to the programme", Robert Banner cautioned the meeting against being led away with the idea that "Republicanism was always synonymous with liberty". ${ }^{58}$ Banner, in other words, rejected the O'Brienites' belief that exploitation depended on the political system. He was a Scottish socialist influenced by the antiparliamentarianism of Andreas Scheu. Herbert Burrows, a socialist convert from the secularist movement, opposed the motion on the different grounds that, whilst he was a Republican to whom politics mattered, he did not think that the public would accept republicanism. Consequently, he moved an amendment that would include the monarchy without mentioning it: the D.F. should demand the "abolition of the House of Lords and all hereditary legislators codies". 59

Charles Murray expressed the views of the O'Brienites when he seconded Burrows' amendment. He said:

The real cause of the evils from which the masses suffered was not the monarchy, but the fact that they were in the hands of capitalists. What they wanted was a social revolution, and believing that the programme of the association was well calculated to advance that social revolution, he seconded the amendment. ${ }^{60}$

It is easy to read current day meanings back into Charles Murray's words and declare him to be a socialist. But if we look closely at his words, we find that they merely extend O'Brienism. Capitalists had replaced landlords as public enemy number one, but capitalist oppression still depended on political power and the monopoly of the land. The clue to Murray's O'Brienism is his last sentence: the D.F.'s programme contained nothing but political measures and land nationalisation and yet this programme would "advance" the social revolution against the capitalist. There was still no indication that collective ownership of the means of production might be necessary.

In "Social Revolution Not Political Reform" Banner argued both that political reforms were useless - "parliamentary government is a mockery, and the cry for the franchise a sham" - and that land nationalisation would favour only the capitalist - "nationalisation of the Land alone will not benefit the toilers but the non-toilers, for it will increase the capital at their disposal, and will give them a greater command over all commodities in the market". ${ }^{61}$ The implication that only expropriation of the capitalist would

${ }^{58}$ Radical, 3 June 1882. It was not until 1884 that Edward Carpenter's donation enabled the D.F. to publish Justice. It is, therefore, necessary to search other newspapers for information on the early history of the D.F. The Radical is the most useful.

${ }^{59}$ Radical, 3 June 1882.

${ }^{60}$ Ibid. 
suffice took Banner beyond O'Brienism to socialism.

The O'Brienites, however, thought differently. When Morgan lectured the M.S.L. on "The Programme of the Democratic Federation", he placed the D.F. squarely within the radical tradition: referring to the inaugural conference, he said that "there never was a conference of more genuine Radicals". ${ }^{62}$ Unlike Banner, Morgan enthused about the D.F.'s political stance saying that "the political part of the programme meant a thorough reform of the House of Commons, and it was useless to expect any radical reform from a House that was composed of landlords, capitalists, contractors, employers of labour, and speculators". ${ }^{63}$ A reformed parliament, by implication, would be useful. Similarly, the O'Brienites strongly favoured land nationalisation. Edmund Jones believed that the land question was "the most important of all human considerations", whilst Morgan thought that "the unanimous vote in favour of the nationalisation of the land showed that the delegates were sound upon the land question, and it only required a few more such conferences to be held over the country to make it the question of the day". ${ }^{64}$ Further, Lord's talk on "Irish Land and British Labour" showed that the O'Brienites still saw the ills of capitalism as dependent on the unnatural system begun by political oppression and the denial of land rights. The capitalist continued the system of monopolisation begun by the landlord: "the lecturer drew a comparison between the position of the Irish tenant, who depended upon the landlord for permission to cultivate the land, and the British workman, who depended upon the capitalist for leave to work" ${ }^{65}$ Capitalists took a tribute as monopolists and as middlemen. They stood alongside landlords and moneylords:

The annual wealth produced by the workers was $950,000,000$ sterling, while the producers received in wages only $250,000,000$. The balance of $700,000,000$ was appropriated by landlords, profitmongers, and capitalists. ${ }^{60}$

The O'Brienites, then, wanted a social revolution but they still believed that they could secure a social revolution by political reforms and land nationalisation alone. Thus, the programme of the D.F. would produce a social revolution. The O'Brienites differed from Banner not on the need for social change but on the means by which to obtain social change. Banner demanded expropriation of the capitalist; the O'Brienites continued to demand a representative political system and nationalisation of the land, they still did not call for collective ownership of the means of production.
${ }^{61}$ Radical, 29 April 1882.
${ }^{62}$ Radical, 25 June 1881: for the lecture's title see Radical, 18 June 1881.
${ }^{63}$ Radical, 25 June 1881.

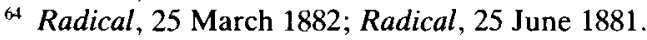
${ }^{65}$ Radical, 2 April 1881.
${ }^{6}$ Ibid. 
In the winter of 1882-1883 the D.F. held a series of conferences on "stepping stones", that is social reforms such as the eight-hour day and public work for the unemployed.$^{67}$ In 1883 Hyndman and Morris wrote a manifesto for the D.F. that called for the immediate adoption of these stepping stones and declared that the D.F. was a socialist organisation. ${ }^{68}$ In 1884 the D.F. took the title S.D.F. and adopted a new programme that called for "the production of wealth to be regulated by society in the common interest" and for "the means of production, distribution and exchange to be declared and treated as collective or common property" ${ }^{69}$

By this time the O'Brienites accepted the need to collectivise the means of production. They had moved away from O'Brienism towards socialism. They now put more emphasis on the struggle between wage-earners and wage-payers. They were now more equivocal about the idea that social evils originated in a corrupt political system, often talking instead of the social causes of social evils. And, most importantly, they now demanded collective ownership of the means of production. We should, however, note that the O'Brienites retained much of their O'Brienism. Their socialism merely attached aspects of vulgar Marxism to their earlier beliefs. There was no sudden conversion to a "true" socialism but rather a shift in the language of radicalism. The process involved subtle not absolute changes in the O'Brienites social theory, though the subtle changes did give rise to a new demand for collective ownership of the means of production.

The level of continuity in the beliefs of members of the D.F. can be striking, as in James Murray's article on "Our Duty Towards the Slaves of the Soil". The people were his constituency and the rulers' monopoly of political power underlay all exploitation:

Socialists must take in hand the task of making plain to the tillers of the soil, that their poverty, as also the poverty of all useful men, has a common origin. That the remedy for all is the same. That the sufferings of the people are the outcome of criminal legislation in the interests of the exploiting classes. ${ }^{70}$

Further, the land monopoly remained a pre-condition of capitalist exploitation, for with agriculture "crushed and cowed, the bulwark of defence was gone that stood in the way of the subjugation of all". ${ }^{71}$

Many D.F. members, however, shifted their viewpoint in a way that led them to advocate abolition of the private ownership of the means of

67 Justice, 9 August 1884.

${ }_{68}$ The Democratic Federation, Socialism Made Plain.

69) Justice, 25 October 1884 .

${ }^{70}$ Justice, 30 August 1884.

${ }^{71}$ Ibid. 
production. They developed a slightly different notion of class that made the wage relationship central: a socialist revolution "will abolish all distinctions of class, or difference between wage-payers and wage-earners, and will render the workers their own employers". ${ }^{72}$ They saw social evils as independent of political causes: Justice told the workers that "their bad food, bad housing, bad education, bad clothing, are all directly due to the social oppression from which they suffer". ${ }^{73}$ Thus the O'Brienites now argued that "social changes need social action". ${ }^{74}$ Further, because capitalist exploitation was separate from the land monopoly, to end wage slavery one had to nationalise the means of production as well as the land.

Despite these shifts of belief, there was much continuity in the outlook of the O'Brienites. The talk might be of the wage-earners not the people but the wage-earners were still juxtaposed with idle monopolists; landlords, moneylords, and capitalists were all alike. Thus, Justice was to "preach discontent to the wage-earning classes, and call upon them to show a bold front to the landlords and capitalists". ${ }^{75}$ The capitalists might be an independent evil set against the workers, but their ability to exploit the workers depended on a monopoly, their exclusive ownership of the means of production, and so was parallel to the exploitation of the workers by the landlords:

The landlords monopolise the land, and the capitalists the machinery [ . . ]. How does the capitalist act? He extorts from those labourers who are excluded from the land a share of all that they produce, under threat of withholding from them the implement of production. ${ }^{76}$

A new monopoly meant a new exploiting class but the mechanism of exploitation remained a monopoly. The O'Brienites could not have held Marx's theory of surplus value because they did not distinguish use value from exchange value. ${ }^{77}$ Consequently, the members of the D.F. explained capitalist exploitation as follows. The worker takes four hours a day to produce commodities the value of which is equal to the worker's subsist-

72 Justice, 10 May 1884.

73 Justice, 29 March 1884.

${ }^{74}$ Ibid.

75 lbid.

${ }^{76}$ Ibid.

7 This was true of most British Marxists and their socialist critics in the early $1880 \mathrm{~s}$. See H. Hyndman, The Text Book of Democracy: England for All (London, 1881); W. Morris, "Monopoly or How Labour is Robbed", in The Collected Works of William Morris, introduction M. Morris, 24 Vols (London, 1910-1915), vol. 23: Signs of Change, Lectures on Socialism; S. Olivier, "Perverse Socialism", To-day (1886), pp. 47-55 and 109-114, and S. Webb, "Rent, Interest and Wages: Being a Criticism of Karl Marx and a Statement of Economic Theory”, Passfield Papers, British Library of Political and Economic Science, London, VII:4. 
ence, but the capitalist uses a monopoly of machinery to force the worker to labour for ten hours a day (the capitalist will allow the worker to labour the necessary four only if the worker labours for the extra six hours and the worker must accept as he will starve if he does not). The value produced in the additional six hours is therefore surplus value which the capitalist appropriates. As Harry Quelch said, "it is by overwork that the surplus value is created upon which the idlers live". ${ }^{78}$ Certainly capitalists obtained surplus value only by purchasing labour, but they did so because their monopoly of machinery and an iron law of wages meant that they could buy labour for subsistence wages, not because of the relationship of labour to value. It was the capitalists' monopoly of machinery that forced the workers "to sell their labour for a bare subsistence wage". ${ }^{79}$

This theory of exploitation sat comfortably alongside many O'Brienite themes. Capitalists could be seen as middlemen who obtained surplus value by interposing themselves between the producers and the machinery:

Who are the middlemen who intercept and share the surplus-value produced by the labourer? The unnecessary agents and distributors, the holders of stocks, bonds, and shares of every description, and all those who are supported by the wealth-producers either in idleness or useless-labour. ${ }^{80}$

Thus, the struggle still appeared to be one between workers and idlers. Capitalists were condemned as monopolists, but in so far as they worked they were useful: "those who organise labour are always worthy of their hire", [. . . "it is only the absolutely idle who are simply the enemies of the workers". 81

The O'Brienite members of the S.D.F. believed that capitalist exploitation derived from a monopoly, an artificial imposition on a natural exchange process, not, as many other Marxists believe, from a particular mode of production. Society was a natural institution corrupted by various monopolies each of which produced an independent distortion, not a totality determined by a particular mode of production. (I am not here concerned with the question of what Marx himself thought or of what is in fact the case: I do not want to make a distinction between the views of the O'Brienites and some form of "true" socialism: I am concerned merely to elucidate the views of the O'Brienites by distinguishing them from one possible alternative.) Just as capitalist exploitation was independent of political injustices and the land monopoly, so political injustices and the land monopoly were independent of capitalist exploitation. The state, for

78 Justice, 31 May 1884.

79 Justice, 19 January 1884.

80 Justice, 7 June 1884.

81 Justice, 29 March 1884. 
instance, acted in the interests of the oppressors, but it did so only because it was an unrepresentative imposition upon a natural social order. Thus radicals could successfully reform the state or nationalise the land without encroaching on the capitalists' monopoly of machinery, though to do so would be to achieve only partial reform since completely to reform society socialists would have to eliminate every distortion including the capitalists' monopoly. Capitalism, therefore, was just an additional distortion blocking O'Brien's ideal, and nationalisation of the means of production just an additional requirement for realising O'Brien's ideal.

The subtle changes in the views of the O'Brienites became clear at a special meeting of the D.F. at Anderton's Hotel in January 1884. Hyndman opened the proceedings by showing how the workers were exploited and why exploitation made nationalisation of the means of production a necessity. The purpose of the meeting, however, was to decide how to reach the socialist goal. Here Hyndman argued that the D.F. should "take advantage of the growing influence of the State, so that it might be dominated and used by the workers instead of by the middle, capitalist and landlord classes". ${ }^{82}$

James Murray, the O'Brienite, supported Hyndman. He proposed a resolution saying that "this meeting of Socialists demands universal suffrage, proportional representation and payment of members as a means of obtaining reduction of the hours of labour, socialisation of the means of production, and the organisation of Society" ${ }^{83}$ James Murray's resolution embodied the new socialist outlook of the O'Brienites. He demanded collective ownership of the means of production. Yet he thought that political evils were independent of social evils - capitalists and landlords dominated the political system but that they did so was not a necessary facet of a capitalist society. Thus radicals could reform the political system without first reforming the social system. Further, a reformed political system could serve as an instrument with which to reform the social system. True, a reformed political system would not by itself create a socialist society, but it would be a tool for creating a socialist society. A truly democratic state would give political power to the workers who could then use political power to nationalise the land and the means of production. Only if so used, however, would a democratic state promote the socialist ideal:

Abolition of the House of Lords, Universal Suffrage, Payment of the Expenses of Elections out of the Rates, and Payment of Members - these measures would, for the first time in our history, place supreme political power in the hands of the mass of the people [...]. But, Fellow-Citizens, what will you do with the suffrage when you get it? [ . . ]. It has but one use, to enable the workers, as a

${ }^{82}$ Justice, 19 January 1884.

${ }^{83}$ Ibid. 
class, to take possession of the power of the State so as to use that power for social purposes. ${ }^{84}$

H.H. Champion made a similar point when he seconded James Murray's resolution:

He did not believe that political remedies would cure social evils, which were just as rife under republics as under autocracies. But he wished to see universal suffrage, and desired thorough political reforms with the distinct object of bringing about social reconstruction. ${ }^{85}$

Political measures, then, were not a complete cure, but they were a means to a complete cure. The socialism of many members of the D.F. still embraced O'Brien's political strategy according to which the immediate need was for political reforms which once introduced would enable the workers to initiate social reforms. The difference was that the social reforms required of a democratic parliament now included nationalisation of the means of production as well as nationalisation of the land.

Two main groups within the D.F. disagreed with the O'Brienites' analysis. The first completely rejected politics and "trusted more to social agitation". ${ }^{86} \mathrm{Mr}$. Setternick, for instance, opposed James Murray's resolution and proposed an alternative declaring that "in the opinion of this meeting [...] the working classes of this or any other country cannot depend any longer upon parliamentary representation to better the condition of the wage-slaves" ${ }^{87}$ Charles Murray immediately opposed Setternick's resolution. The O'Brienites could not accept Setternick's statement because they believed that although political reform was not all that was necessary, it was both part of what was necessary and a means of promoting the other reforms that were necessary. Edward Aveling represented the other group who disagreed with the O'Brienites. ${ }^{88}$ He neither rejected political action nor believed that political reform would facilitate social reform. Instead, he saw participation in political movements as a way of obtaining working class support for social reforms. The point was not to obtain political ends as a means to social ends but to take part in political movements as a way of promoting social movements.

In the first half of 1884 Hyndman and the O'Brienites had the upper hand. The programme of the D.F. concluded with a call for political

${ }_{84}$ Justice, 12 July 1884.

${ }^{85}$ Justice, 19 January 1884.

${ }^{86}$ Ibid.

${ }^{87}$ Ibid.

${ }^{88}$ On Aveling see Y. Kapp, Eleanor Marx, 2 vols (London, 1979), and C. Tsuzuki, The Life of Eleanor Marx 1855-1898 (Oxford, 1967). For his beliefs see E. Aveling, The Students' Marx (London, 1892). 
reforms as a preliminary to social palliatives:

The Democratic Federation, as a means by which these [social palliatives] are to be attained, calls for -

1. Adult Suffrage.

2. Annual Parliaments.

3. Proportional Representation.

4. Payment of members, and Official Expenses of Elections, out of the Rates. ${ }^{89}$

\section{Explaining the Change}

It is difficult to explain why beliefs change. In the case of the O'Brienites' shift to socialism there seem to have been relevant factors in both their intellectual and social environments. They changed their views after the founding of the D.F. and it seems likely that to some extent they were swept up by the impetus of the socialist revival. After all, everyone was talking about socialism and Harcourt was soon to make his famous statement that "we are all socialists now". Marx had published little in English so the O'Brienites would not have been reading his works in the $1870 \mathrm{~s} .{ }^{90}$ The collapse of the Paris Commune and Bismarck's anti-socialist laws of 1878, however, forced many socialists to flee to London and some of these socialists entered the world of the London clubs. ${ }^{91}$ Shaw took French lessons from Richard Deck, Bax met Hermann Jung and Johann Most at the London Dialectical Society in Poland Street, and Adam Weiler gave a lecture to the M.S.L. on The Communist Manifesto. ${ }^{92}$ Hyndman entered the world of the O'Brienites soon after the influx of exiles from the continent and soon he was publicising his brand of Marxism with remarkable zeal. He published books and articles, wrote polemical tracts against Samuel Smith and Herbert Spencer, lectured, organised discussions, and held a public debate with Charles Bradlaugh. ${ }^{93}$

${ }^{89}$ Justice, 5 April 1884.

90 For when Marx's works became available in England see, Macintyre, Proletarian, pp. 91-93.

91 On the exiles see, H. Olivier, The International Anarchist Movement in Late Victorian London (London, 1983); J. Quail, The Slow Burning Fuse (London, 1978), and Thompson, Morris, pp. 276-287.

92 G. Shaw, "Autobiographical Notebook", The Shaw Papers, The British Museum, London, BM50710; E. Bax, Reminiscences and Reflections of a Mid and Late Victorian (London, 1918), pp. 39-42; Labour Standard, 1 October 1881.

${ }_{93}$ His main books were, Hyndman, England, and H. Hyndman, The Historical Basis of Socialism in England (London, 1883). His polemical pamphlets were, H. Hyndman, Socialism vs Smithism (London, 1883), and H. Hyndman, Socialism and Slavery (London, 1884). For the debate see $\mathrm{H}$. Hyndman and $\mathrm{C}$. Bradlaugh, Will Socialism Benefit the 
If we locate the O'Brienites' adoption of collective ownership within the socialist revival itself, then we can also explain why their new beliefs took the form that they did. Neither the exiles nor Hyndman distinguished between use value and exchange value. Many of the French exiles were mutalists, Deck introduced Shaw to Proudhon not Marx, and many of the German exiles were Lassaleans, Scheu firmly believed in the iron law of wages. Hyndman gave the delegates to the inaugural conference of the D.F. a copy of his England for All in which he explained surplus value by saying that the workers needed to work four hours to produce their subsistence but that the capitalists' monopoly enabled them to force the workers to work for ten hours. The O'Brienites merely picked up the economic doctrine of those around them.

When we turn to the social context of the O'Brienites shifting beliefs, we should bear in mind that recent work indicates that British industry was still overwhelmingly skill intensive in the 1880 s; industrialisation was patchy, employers often retained hand labour because of its flexibility and the expense of mechanisation, and new techniques created new skills as well as destroying old skills. ${ }^{94}$ George Harris was a tailor, Charles Murray, James Murray, William Morgan, and William Townshend were shoemakers, and Richard Butler was a compositor. ${ }^{95}$ The creeping advance of mass production only slightly affected these trades during the 1860 s and 1870 s. Further, the O'Brienites were Londoners employed in the bespoke trade of the West End which often relied on pre-industrial techniques and which, although altered by the market economy, still consisted of skilled craftsmen working individually or in small groups - perhaps wage workers but definitely not machine operatives. The world of the O'Brienites was fairly stable during the mid-Victorian era. Further, it is probable that these O'Brienites were representative of much of the D.F.'s dues-paying membership which in the 1880 s averaged only five hundred and eighty, of whom less than one hundred lived outside of London. ${ }^{96}$ In the early 1880s, however, things

English People? (London, 1884).

94 Samuel, "Workshop of the World".

${ }^{95}$ On tailors see M. Stewart and L. Hunter, The Needle is Threaded (London, 1964); B. Drake, "The Tailoring Trade", in S. Webb and A. Freeman, (eds), Seasonal Trades (London, 1912), pp. 70-91 and S. Dobbs, The Clothing Workers of Great Britain, introduction S. Webb (London, 1928). On shoemakers see A. Fox, A History of the National Union of Boot and Shoe Operatives (Oxford, 1950), and R. Church, "Labour Supply and Innovation 1800-1860: The Boot and Shoe Industry", Business History, 12 (1970), pp. 25-45. On compositors see B. Alford, "Government Expenditure and the Growth of the Printing Industry in the Nineteenth Century", The Economic History Review, 17 (1964), pp. 96-112, and R. Huss, The Development of Printers' Mechanical Typesetting Methods 1822-1925 (Charlottesville, 1975).

${ }^{96}$ P. Watmough, "The Membership of the Social Democratic Federation 1885-1902", Labour History Bulletin, 34 (1977), pp. 35-40. 
changed rapidly. Nowadays historians tend to dismiss the Great Depression as largely mythical but this should not make us forget that contemporaries, and presumably the O'Brienites, thought that they were living through a depression. ${ }^{97}$ On top of this sense of unease, Londoners experienced drastic changes in the local labour market as industries such as shoemaking and shipping migrated to towns such as Northampton and Gravesend. ${ }^{98}$ Further, the bespoke trades of the O'Brienites entered a period of deskilling and mechanisation with mechanical typesetting, for instance, taking employment away from many skilled hand-setting compositors. Here, then, was the social backdrop to the O'Brienites' evolving beliefs.

\section{Understanding the Social Democratic Federation}

Over a quarter of a century ago Eric Hobsbawm observed that "the Social Democratic Federation has long been the problem-child of labour historians, especially Marxist ones or those anxious to 'place' it rather than merely to chronicle its erratic development". ${ }^{99}$ It still is. Paradoxes surround the story of the S.D.F. Why did the membership follow the lead of an autocratic aristocrat? Why when the S.D.F. supposedly propounded dogmatic Marxism is it criticised for opportunism? And why did the S.D.F. out perform the Independent Labour Party in London but almost nowhere else? By way of a conclusion I will try to show how the O'Brienite roots of the members of the S.D.F. helps to explain these paradoxes.

First, the members of the S.D.F. accepted Hyndman's leadership because his beliefs overlapped theirs at important points. The O'Brienites' popular and Hyndman's Tory radicalism both derived from the discourse of the country party. ${ }^{100}$ Thus Hyndman could link his socialist ideal to a radical tradition that culminated in O'Brien:

Is there nothing inspiring in such an ideal [. . ]? There is to me. That for which generations have striven vainly is now possible to us [. . .] Tyler and Ball, and Cade and Kelt, Vane and Blake and Harrison, Priestly and Cartwright, Spence

${ }^{97}$ The revised view of the depression began with $\mathrm{H}$. Beales, "The Great Depression in Industry and Trade", Economic History Review, 5 (1934), pp. 65-75, and appears in E. Hobsbawm, Industry and Empire (Harmondsworth, 1969), and S. Paul, The Myth of the Great Depression 1873-1896 (London, 1969).

${ }^{88}$ G. Stedman Jones, Outcast London (Oxford, 1971), esp. pt.1.

99 E. Hobsbawm, "Hyndman and the S.D.F.", in Labouring Men (London, 1964), p. 231.

${ }^{100}$ On the country party and the origins of radicalism see C. Robbins, The Eighteenth Century Commonwealth Men (Cambridge (Mass.), 1959); J. Pocock, The Machiavellian Moment (Princeton, 1975), and M. Peters, "The 'Monitor' on the Constitution, 17551765: New Light on the Ideological Origins of English Radicalism", English Historical Review, 86 (1971), pp. 706-727. 
and Owen, Vincent, Ernest Jones, and Bronterre O'Brien - a noble band indeed! [ . . ] How do courtly fuglemen and ennobled sycophants look by the side of these? A great democratic English Republic has ever been the dream of the noblest of our race [. . .]. To bring about such a Republic is the cause for which we Socialists agitate to-day..$^{101}$

In particular, Hyndman and the O'Brienites advocated similar political strategies. They thought that the S.D.F. should start by struggling to create a democratic state that the workers could then use to end social evils. The membership, in other words, accepted Hyndman's leadership because his strategy was their strategy.

Once we understand what bound the members of the S.D.F. to Hyndman, we can make sense of the split in the S.D.F. that led to the formation of the Socialist League. Historians often stress the role of Hyndman's dictatorial and jingoistic attitudes which, no doubt, played a part. But ascribing importance to Hyndman's attitudes raises as many questions as it answers. If Hyndman's unpleasantness was the main cause of the split then why did the members follow Hyndman and not Morris? E.P. Thompson refers us to Morris' tactical blunders and to the failure of the members to understand the dispute:

The fact is that to the membership the whole thing appeared as a mystery. They knew nothing of the history of the dispute: and the majority, by refusing to submit it to a general meeting, seemed afraid to consult them. ${ }^{102}$

Are we really to believe that the membership did not understand the issues despite regular warnings about Hyndman and despite Hyndman's blatantly jingoistic writings? Even if the members did not know that Hyndman's authoritarianism and chauvinism were part of the issue, which I doubt, they surely must have been aware of Hyndman's attitudes in more general terms, and yet they nonetheless sided with him. In my opinion the bulk of the membership stuck by Hyndman because, like them, but unlike the founders of the Socialist League, he wanted political reforms to create a democratic state as a preliminary to ending capitalist exploitation.

My explanation differs from Tsuzuki's suggestion that the theoretical issue beneath the dispute was whether or not the S.D.F. should undertake electoral action. ${ }^{103}$ If we emphasise the question of parliamentarianism, the behaviour of the Avelings seems peculiarly perverse since they later left the Socialist League precisely because it opposed electoral action. The note that formed the Socialist League was signed by anti-parliamentarians such

101 Justice, 14 June 1884.

102 Thompson, Morris, p. 364.

${ }^{103}$ Tsuzuki, Hyndman, pp. 60-67. Also see M. Beer, A History of British Socialism, 2 vols (London, 1953), 2, p. 253. 
as Banner, but also by people who shared Aveling's belief that participation in movements for political reform could increase support for movements demanding social reform. ${ }^{104}$ The people who signed the note in defence of Hyndman, in contrast, saw political action and political reforms as the way to promote social reforms. ${ }^{105}$ Thus, after the split the S.D.F. held an extraordinary conference that carried a motion that reinstated the Federation's old programme with its demand for political reforms as a means of obtaining social ends, and another resolution asserting that "it is advisable for the Social Democratic Federation to take political action in whatever way circumstances and the tactics of our opponents may suggest". ${ }^{106}$

Second, the S.D.F.'s ideology was dogmatic because it talked of Marxism as an economic and historical science, whilst the S.D.F.'s actions were opportunistic because it sought political power as a means to socialism. Most historians argue that the S.D.F. opposed trade unions because the leaders of the S.D.F. held an iron law of wages and saw the unions as a labour aristocracy. ${ }^{107}$ Yet the leaders of the S.D.F. came to reject the iron law of wages and the new unionism clearly encompassed unskilled workers. ${ }^{108}$ The main source of the S.D.F.'s ambiguous attitude to trade unions was, then, an overriding concern with political reforms as a means to social ends. Thus, Hyndman complained to Henry George that the unions had never "used what organisations they have for definite political purposes". ${ }^{109}$ With the emergence of new unionism and Hyndman's rejection of the iron law of wages, the S.D.F. opposed only the apolitical nature of trade unionism. Thus, unions were a good thing if they accepted socialism and worked for the political reforms that would advance socialism, but they were insignificant if they concerned themselves solely with industrial issues.

The ambiguous nature of the S.D.F.'s attitude to palliatives had similar origins. E.P. Thompson argues that Hyndman wanted to use a workers' party to threaten the government and that,

Such an intention was consistent with a half-concealed feeling of contempt for the workers. At one moment he set forward the 'palliatives' as a cry to rally discontent: at another he spoke with utter contempt of such half-measures. The

${ }^{104}$ The signatories were, Aveling, Eleanor Marx-Aveling, Banner, Bax, W. Clarke, Cooper, Joseph Lane, John Mahon, Sam Mainwaring, and Morris.

${ }^{105}$ The signatories were, John Burns, Burrows, Champion, Robert Frost, Mrs. Hicks, Hyndman, J. Murray, Quelch, and Williams.

${ }_{106}$ Justice, 11 April 1885. The "old programme" was that cited above since the S.D.F. had adopted a new programme based on that of the anarchistic Labour Emancipation League.

${ }_{107}$ See Collins, "Marxism"; Thompson, Morris, p. 336; D. Torr, Tom Mann (London, 1956), p. 213, and Tsuzuki, Hyndman, pp. 55-56.

${ }^{108}$ There is no iron law of wages in H. Hyndman, The Economics of Socialism (London, 1896).

${ }^{109}$ Radical, 15 April 1882. 
'stepping-stones' were the carrot for the donkey: and the donkey was the people. ${ }^{110}$

Certainly Hyndman glorified the Tory ideal of statesmanship and saw himself as the man to save England from impending catastrophe, but this was not the source of his troubled view of palliatives. If it had been, then the members would not have shared his views and so he would have had trouble imposing his views on the S.D.F. Both Hyndman and the O'Brienites, however, believed that whilst social palliatives could improve the condition of the workers, they could not create socialism. Socialism required political action to obtain political reforms to establish a democratic state that could legislate to end social exploitation. Social palliatives, therefore, were most useful as a rallying cry to mobilise the workers into a political party.

Finally, the S.D.F.'s O'Brienite heritage throws light on the S.D.F.'s regional strengths. P. Thompson has shown that the S.D.F. was the strongest of the early socialist groups in London and that the S.D.F.'s other regional base was Lancashire. He explains this distribution of support by local religious traditions arguing that in Lancashire "catholicism provided the same kind of preparation for a doctrinal Marxist socialism as did secularism in London". ${ }^{111}$ Thompson's explanation helps, but it is only part of the story. Another determinant of S.D.F. influence was the local political tradition. In the 1880 s London was the centre of O'Brienism whilst Lancashire possessed a tradition of working-class conservatism and both of these political traditions complimented Hyndman's Tory socialism. ${ }^{112}$ The history of the Clarion group indicates the importance of including local political traditions in our explanation of the regional strengths of the S.D.F., for the Clarion group thrived in catholic Lancashire despite lacking theoretical dogmatism. It thrived because the working class conservatives of Lancashire responded to the Tory socialism of Robert Blatchford. ${ }^{113}$

110 Thompson, Morris, p. 341.

111 P. Thompson, Socialists, Liberals and Labour (London, 1967), p. 114 - for membership figures see Appendix B.

112 On working class Toryism in Lancashire see D. Howell, British Workers and The Independent Labour Party 1888-1906 (Manchester, 1983), pp. 204-229.

113 See L. Barrow, "The Socialism of Robert Blatchford and the Clarion Newspaper 1889-1918" (Ph.D. thesis, London, 1975), and L. Thompson, Robert Blatchford (London, 1951). For Blatchford's beliefs see R. Blatchford, Merrie England (London, 1894), and R. Blatchford, Britain for the British (London, 1902). 